\title{
Effects of Oxidized Brown Coal Humic Acid Fertilizer on the Relative Height Growth Rate of Three Tree Species
}

\author{
Ganchudur Tsetsegmaa ${ }^{1,2}$ (D), Khaulenbek Akhmadi ${ }^{2}$, Wonwoo Cho ${ }^{1,3}$, Sora Lee ${ }^{1}$, \\ Romika Chandra ${ }^{1}$, Choi Eun Jeong ${ }^{1}$, Rogers Wainkwa Chia ${ }^{1}$ and Hoduck Kang ${ }^{1, *}$ \\ 1 Department of Biological and Environmental Science, Dongguk University Biomedi Campus, \\ Goyang-si 10326, Korea; ganchudur_cds@yahoo.com (G.T.); wonwoo.c@gmail.com (W.C.); \\ ssora4rang@nate.com (S.L.); romika.chandra@gmail.com (R.C.); cej4277@gmail.com (C.E.J.); \\ chiarogers2013@gmail.com (R.W.C.) \\ 2 Mongolian Academy of Sciences, Institute of Geography \& Geoecology, Ulaanbaatar 16062, Mongolia; \\ a.khaulenbek@gmail.com \\ 3 National Institute of Forest Science, Division of Forest Tree Improvement, 39 Onjeong-ro, \\ Suwon 16631, Korea \\ * Correspondence: hdk0225@dongguk.edu; Tel.: +82-10-3307-3316
}

Received: 17 May 2018; Accepted: 13 June 2018; Published: 17 June 2018

\begin{abstract}
This study aimed to identify the effects of oxidized brown coal humic acid fertilizer on the relative growth rate of several tree species intended for reforestation. Field experiments were carried out during 2011-2014 at the Research and Experimental Center for Combating Desertification located at the Elsen Tasarkhai station in central Mongolia. The trees studied were Populus sibirica Tausch., Salix ledebouriana Trautv., and Acer tataricum L. The experiment was conducted with concentrations of 2000, 10,000, and 20,000 $\mathrm{mg} \mathrm{L}^{-1}$ of humic acid fertilization treatment. Measurement of the relative height growth rate (RHGR) was undertaken for a period of four years. The results demonstrated significant differences between the humic fertilizer concentrations, which varied depending on the species. Compared to monthly RHGR over the study period, the treatment using fertilizers yielded significantly better tree growth. P. sibirica, when treated with $2000 \mathrm{mg} \mathrm{L}^{-1}$ and $10,000 \mathrm{mg} \mathrm{L}^{-1}$ humic acid fertilizers, had significant height growth rates. S. ledebouriana with $20,000 \mathrm{mg} \mathrm{L}^{-1}$ of humic acid fertilzers treatments showed the highest RHGR. In addition, when the humic acid treatments were compared to the control, results showed that oxidized brown coal humic acid fertilizers as an organic fertilizer can have a significant effect on the growth of $A$. tataricum. The results equally showed that the soil chemical properties $\mathrm{EC}, \mathrm{CO}_{2}, \mathrm{NO}_{3}$, and $\mathrm{K}_{2} \mathrm{O}$ were significant among all the treatments compared to control. The effect on $\mathrm{P}_{2} \mathrm{O}_{5}$ significantly increased in all the treatments; however, there was no significant effect on $\mathrm{pH}$ and $\mathrm{Mg}$ among all treatments. Combining the results obtained with reforestation and sustainable land-management practices can help to improve soil organics in degraded sandy soil regions.
\end{abstract}

Keywords: reforestation; humic acid fertilizer; relative height growth rate; soil chemical properties

\section{Introduction}

Scientific research has established that organic matter plays an important role in controlling the physiochemical properties of soils [1,2]. Residues from the partial oxidation of the dead biomass of plants is considered to be the source of organic substances that are added to soil as humus [3-5]. Currently, there is an increase in the quantity of humic-based products available to plant growers. These have various sources, ranging from hard black coal that is composted with plant matter and manure 
to complex and richer humic sources such as brown coal, peat, and leonardite [4,6,7]. Leonardite is a medium-brown coal that contains the most complex and bio-active form of humic components [8]. Humic substances (HS) are the major organic components of the Earth's soils and sediments that were created from decayed bio matter by a process called humification [1]. HS are found in especially high concentrations in peat and brown coals [9]. Different grades of coal are formed by the geological compression of soil layers over millions of years. The lower ranks of coal such as lignite (brown coal) and sub-bituminous coals are not efficient as fuel for energy but contain large amounts of organic matter [10]. During humification, with the aid of millions of micro-organisms, the simple products of decomposition like amino acids, carbohydrates and phenols turn into very complex, long-chain organic compounds with high molecular weight called humic acids (HA) that are derived from vegetation. This material is very rich and beneficial for plant growth as an environment-friendly resource [11]. HAs are complex molecules that exist naturally in soils, peats, oceans and fresh water $[12,13]$. The best source of HAs is the soft sedimentation layers of leonardite, an organic material found beneath the Earth's surface in the cold climes of the United States, Russia, and Mongolia [14]. Often referred to as oxidized lignite, these layers are the richest as well as the most economical source of HA from leonardite, a naturally occurring oxidized form of lignite coal $[15,16]$. HS are the subject of research in different fields of agriculture that include soil chemistry, fertility, plant physiology, and environmental sciences. This is due to the multiple roles played by these substances that have highly beneficial effects on plant growth directly or indirectly $[4,17,18]$. HS are the end products of the organic decomposition of biotic compounds constituting between $50-90 \%$ of the organic matter of peat, lignite, sapropels, and the non-living organic matter of soil and water ecosystems [19-21]. These substances play a vital role in the soil's function and structure [22]. They can be useful for living organisms in developing food, enzyme metabolism and substrate material, as a carrier of nutrition, as catalysts of biochemical reactions, and in antioxidant activity [23-25]. It has been argued that HS can both directly and indirectly affect the physiological processes of plant growth.

Commercial products derived from lignite, sold mainly as humate preparations, have been widely developed as plant-growth stimulants aimed at increasing crop yield $[3,26]$. These products are also claimed to improve key indicators of soil health including soil $\mathrm{pH}$ and microbial biomass [27]. The sorption of sulfathiazole through three structural analogs to leonardite HA has been investigated in single and binary solute systems in order to elucidate the sorption mechanism of sulfonamides in soil organic matter. High-affinity cation binding explains the absorption and adsorption of polar sulfonamides within crop soils and the strong relationship of adsorption and absorption on soil organic matter content and $\mathrm{pH}$ [28]. It is difficult to identify the difference between the direct and indirect effects of these substances. In fact, some of their positive consequences can be assigned to general enrichment of the soil's fertility and hence the higher availability of nutrients [29]. Mongolian hereditary manure has traditionally been used for farming, but other types of fertilizer used in neighboring countries are also imported. Rapid population growth, desertification, and land degradation means that it is necessary in reforestation and agriculture to improve the productivity of locally produced low-cost, environmental friendly bio-fertilizer use. In Mongolia, there are several mines and seams of carbon-rich mineral deposits containing good agricultural-grade humic substances [30,31]. A study by the Mongolian Academy of Sciences, Institute of Chemistry and Chemical Technology, on the non-energy derived from oxidized brown coal humic fertilizers was used in our experiment. Locally produced brown coal humic soil fertility is useful for reforestation, impact identification and achieving desirable volume suitable for fertilization. HA can reduce the use of the chemical fertilizers that cause environmental pollution, and the lower expenditure of these fertilizers consequently means lower costs $[7,32]$. The aim of this study was to determine the effects on reforestation activity of non-energy derived from oxidized brown coal HS in a degraded sandy soil region. In reforestation applications, HS have the advantage that they are $100 \%$ organic, compatible with sustainable land-management practices, and help to address environmental issues such as desertification and land degradation. 
The present study highlights plant-growth promoting oxidized brown coal as an alternative to fertilizers that is also environmental friendly.

\section{Materials and Methods}

\subsection{Study Area}

This study was carried out at Elsen Tasarkhai station of the Research and Experimental Center for Combating Desertification $\left(47^{\circ} 27^{\prime} \mathrm{N}, 103^{\circ} 68^{\prime} \mathrm{E} ; 1967 \mathrm{~m}\right.$ a.s.l), located in Khugnu-Tarna National Park in the Rashaant district of Bulgan province, central Mongolia. Summary of ecosystem chracteristics and soil chemical and physical properties of the research area shown in Table 1 . The study area has a semi-arid continental climate that is characterized by average annual minimum and maximum temperatures of $22{ }^{\circ} \mathrm{C}$ and $-20{ }^{\circ} \mathrm{C}$, respectively, whereas the maximum absolute temperature is $36{ }^{\circ} \mathrm{C}$, and the mean annual precipitation has been reported to be $200-250 \mathrm{~mm}$ [33]. The soils at forest-steppe and steppe were soil taxonomy a higher aridity index, classified as Calcic Kastanozems and Calcic Hyposodic Kastanozems, respectively [34,35]. Soil physical properties in the clay $5.57 \%$, silt $4.73 \%$ and sand $89.7 \%$, structures sandy loam with a $\mathrm{pH}$ range between 7.80 and 8.92 [33].

Table 1. Summary of chracteristics of the study site.

\begin{tabular}{|c|c|}
\hline \multicolumn{2}{|r|}{ Chracteristics } \\
\hline Ecosystems & Semi arid areas \\
\hline Location & $103^{\circ} 68^{\prime} \mathrm{E}$ and $47^{\circ} 27^{\prime} \mathrm{N}$ \\
\hline Elevation & $1967 \mathrm{~m}$ a.s.l \\
\hline Major vegetation species & $\begin{array}{c}\text { Caragana microphylla, Artemisia frigida, Poa attenuata and Agriophyllum } \\
\text { pungens }\end{array}$ \\
\hline Land use change history & Livestock \\
\hline Land use management & Khognokhaan Natural Reserve \\
\hline Local ecosystems problem & $\begin{array}{c}\text { Mitigating sand movement in the region with soil } \\
\text { erosion/desertification }\end{array}$ \\
\hline \multicolumn{2}{|r|}{ Climat condition } \\
\hline Mean annual temperature & $-2{ }^{\circ} \mathrm{C}$, ranges from $-20^{\circ} \mathrm{C}$ to $22^{\circ} \mathrm{C}$ \\
\hline Mean annual precipitation & 200 to $250 \mathrm{~mm}$ \\
\hline Wind velocity ranges & 0.5 to $2.3 \mathrm{~m} / \mathrm{s}$ with the maximum in May about $4.0 \mathrm{~m} / \mathrm{s}$ \\
\hline \multicolumn{2}{|r|}{ Soil physical properties } \\
\hline Sand $(\%)$ & 89.7 \\
\hline Silt $(\%)$ & 4.73 \\
\hline Clay $(\%)$ & 5.57 \\
\hline \multicolumn{2}{|r|}{ Soil chemical properties } \\
\hline $\mathrm{pH}(1: 2.5)$ & 8.42 \\
\hline Salt $(\%)$ & 0.06 \\
\hline Electric conductivity $(\mathrm{dS} / \mathrm{m})$ & 6.42 \\
\hline Organic matter $(\%)$ & 0.63 \\
\hline
\end{tabular}

Source: Khaulenbek et al. (2010) [33].

The study area is located surrounding the boundary between forest-steppe and dry steppe zones, based on the plant geographical classification in Mongolian [36].

\subsection{Experimental Design}

This study was conducted in 2011-2014 by the Mongolian Academy of Sciences, (Institute of Chemistry and Chemical Technology) on the non-energy derived from oxidized brown coal humic acid fertilizers. Humic acid fertilizers were used with the following characteristics (wt \%): carbon (C) 60.5; hydrogen $(\mathrm{H}) 3.9$; nitrogen $(\mathrm{N})$ 0.9; oxygen $(\mathrm{O}) 34.7$, respectively [37]. These concentrations were approximately equivalent to field application rates of $2000 \mathrm{mg} \mathrm{L}^{-1}, 10,000 \mathrm{mg} \mathrm{L}^{-1}$, and $20,000 \mathrm{mg} \mathrm{L}^{-1}$ 
oxidized brown coal humic fertilizers $\mathrm{m}^{2} \mathrm{yr}^{-1}$. Humic acid fertilizers mixed with water were used for irrigation twice during the growing seasons for four months with a watering can, using 100 liters of water with $20 \mathrm{~g}, 100 \mathrm{~g}$, and $200 \mathrm{~g}$ of humic acid per solution preparation. Ten-liter sprays were used for each $1 \mathrm{~m}^{2}$ area every time, with irrigation undertaken in a flooding manner. Three-year-old Populus sibirica Tausch., Salix ledebouriana Trautv., and Acer tataricum L. species were used as deciduous trees and shrubs for the monitoring studies. P. sibirica, A. tataricum, and S. ledebouriana are widely distributed natural trees in Mongolia and are the most widely used trees in reforestation [38,39]. This study comprised of a repeated measure design involving a total of 120 trees having four treatments, $\mathrm{HA}_{0.2}\left(2000 \mathrm{mg} \mathrm{L}^{-1}\right), \mathrm{HA}_{10}\left(10,000 \mathrm{mg} \mathrm{L}^{-1}\right)$, and $\mathrm{HA}_{20}\left(20,000 \mathrm{mg} \mathrm{L}^{-1}\right)$ along with control $\mathrm{HA}_{0}$ (without fertilizer). Each treatment has three different tree species (P. sibirica, S. ledebouriana, and $A$. tataricum) with a total of 30 trees per replicate. Trees were planted with spacings of $2 \times 1.5 \mathrm{~m}$. Tree height growth was measured twice a year (Spring and Autumn), and soil analysis was carried out in September 2014. The soil samples for each treatment were collected from three subplots with three replications. A total of 36 samples having four treatments (4 treatments $\times 3$ subplots $\times 3$ replication $\times 1$ mixed soil layer $(0-30 \mathrm{~cm}))$. The surface soil $(0-30 \mathrm{~cm})$ were collected at depths of $0-10,10-20$, and $20-30 \mathrm{~cm}$ using a core sampler $(7 \mathrm{~cm}$ diameter by $10 \mathrm{~cm}$ height) and thoroughly mixed to form a homogeneous sample for analysis. Soil chemical properties were analyzed at the soil laboratory in the Institute of Geography and Geoecology. The soil samples were air dried and sieved through $2 \mathrm{~mm}$-mesh size stainless steel sieve and stored in polyethylene bags until analysis. Particle size distributions of the soil samples were determined by using the hydrometer method, soil $\mathrm{pH}$ and electrical conductivity (EC) in a 1:2.5 soil: water (w:v) extract [40]. Soil car bonate $\left(\mathrm{CO}_{2}\right)$ was determined through the pressure-calcimeter method and organic matter $(\mathrm{OM})$ content using the Walkley-Black method [41,42]. Assimilable phosphoric acid $\left(\mathrm{P}_{2} \mathrm{O}_{5}\right)$ and potassium oxide $\left(\mathrm{K}_{2} \mathrm{O}\right)$ were determined by the Olsen method using a spectrophotometer [43]. Exchangeable magnesium (Mg) and calcium $(\mathrm{Ca})$ were determined with an atomic absorption spectrometer, and nitrate $\left(\mathrm{NO}_{3}\right)$ content was determined by the titration method [43].

\subsection{Statistical Analyses}

Since growth may be related to initial tree size at the beginning of the growth period, relative height growth rate (RHGR) was calculated using the equation below. In the first estimator, tree height is averaged before in-transforming, whereas in the second estimator, the height is in-transformed before averaging. The RHGR was computed according to the following equation:

$$
\mathrm{RHGR}=\frac{1 n H T_{2}-1 n H T_{1}}{t_{2}-t_{1}}
$$

where $n H T$ is the natural logarithm of tree height; $t$ is the time (in months); and the subscript refers to initial and final tree height [44-46]. The relative growth rate (RHGR) of P. sibirica, S. ledebouriana and A. tataricum and soil data were statistically analyzed by one-way analysis of variance (ANOVA) followed by the homogeneity of variance which was verified using Levene's test which failed (for RHGR, the homogeneity test failed for $S$. ledebouriana and for soil data $\mathrm{Ph}, \mathrm{OM}, \mathrm{NO}_{3}, \mathrm{P}_{2} \mathrm{O}_{5}$, $\mathrm{K}_{2} \mathrm{O}, \mathrm{Ca}, \mathrm{Mg}$ ). Hence, Kruskal Wallis non-parametric analysis was used as an alternative (Kruskal and Wallis, 1952). Statistical analysis was conducted using the Statistical Package for the Social Sciences (SPSS) Version 21 (IBM Corp., New York, NY, USA). Statistical significance was accepted at $p<0.05$.

\section{Results}

\subsection{Relative Height Growth Rate (RHGR) during Monitoring Period}

The relative height growth rate (RHGR) showed significant differences for the treatments with increased exposure to brown coal humic fertilizer compared to control treatments (Table 2). 
Table 2. Effect of humic fertilization on the relative height growth rate (RHGR) of Populus sibirica, Acer tataricum, and Salix ledebouriana.

\begin{tabular}{|c|c|c|c|c|c|}
\hline \multirow{3}{*}{ Speices } & \multirow{3}{*}{ Treatments } & \multicolumn{4}{|c|}{ Years } \\
\hline & & 2011 & 2012 & 2013 & 2014 \\
\hline & & \multicolumn{4}{|c|}{ Relative Height Growth Rate $\left(\mathrm{cm}\right.$ month $^{-1}$ ) } \\
\hline \multirow{4}{*}{ P. sibirica } & $\mathrm{HA}_{0}$ & $5.62 \pm 0.89^{b}$ & $5.32 \pm 0.85^{b}$ & $5.99 \pm 0.79^{b}$ & $6.57 \pm 0.89^{b}$ \\
\hline & $\mathrm{HA}_{0.2}$ & $8.30 \pm 0.63^{a}$ & $7.79 \pm 0.60^{\mathrm{a}}$ & $9.12 \pm 0.60^{\mathrm{a}}$ & $9.25 \pm 0.63^{\mathrm{a}}$ \\
\hline & $\mathrm{HA}_{10}$ & $7.98 \pm 0.77^{\mathrm{a}}$ & $7.70 \pm 0.67^{\mathrm{a}}$ & $7.23 \pm 0.77^{a b}$ & $8.15 \pm 0.67^{a b}$ \\
\hline & $\mathrm{HA}_{20}$ & $6.24 \pm 0.62^{\mathrm{ab}}$ & $5.92 \pm 0.43 \mathrm{ab}$ & $7.18 \pm 0.67 \mathrm{ab}$ & $7.61 \pm 0.47 \mathrm{ab}$ \\
\hline \multirow{4}{*}{ A. tataricum } & $\mathrm{HA}_{0}$ & $6.74 \pm 0.74^{\mathrm{a}}$ & $5.12 \pm 0.89^{b}$ & $3.54 \pm 0.61^{b}$ & $2.45 \pm 0.70^{b}$ \\
\hline & $\mathrm{HA}_{0.2}$ & $6.53 \pm 0.68^{a}$ & $5.49 \pm 0.79 \mathrm{ab}$ & $4.15 \pm 0.56^{\mathrm{ab}}$ & $3.32 \pm 0.85^{b}$ \\
\hline & $\mathrm{HA}_{10}$ & $7.10 \pm 0.65^{\mathrm{a}}$ & $7.48 \pm 0.77^{\mathrm{a}}$ & $5.59 \pm 0.85^{\mathrm{a}}$ & $5.61 \pm 0.47^{\mathrm{a}}$ \\
\hline & $\mathrm{HA}_{20}$ & $7.54 \pm 0.60^{\mathrm{a}}$ & $7.80 \pm 0.63^{a}$ & $5.97 \pm 0.59^{\mathrm{a}}$ & $5.70 \pm 0.67^{a}$ \\
\hline \multirow{4}{*}{ S. ledebouriana } & $\mathrm{HA}_{0}$ & $5.87 \pm 0.79^{b}$ & $6.07 \pm 0.38^{b}$ & $5.90 \pm 0.70^{b}$ & $6.53 \pm 0.63^{a}$ \\
\hline & $\mathrm{HA}_{0.2}$ & $6.84 \pm 0.17^{b}$ & $6.41 \pm 0.40^{\mathrm{b}}$ & $7.51 \pm 0.61^{\mathrm{ab}}$ & $6.97 \pm 0.48^{\mathrm{a}}$ \\
\hline & $\mathrm{HA}_{10}$ & $6.91 \pm 0.49^{b}$ & $6.62 \pm 0.81^{b}$ & $6.90 \pm 1.50^{a b}$ & $7.88 \pm 0.54^{\mathrm{a}}$ \\
\hline & $\mathrm{HA}_{20}$ & $9.97 \pm 1.61^{\mathrm{a}}$ & $8.36 \pm 0.57^{\mathrm{a}}$ & $9.91 \pm 1.61^{\mathrm{a}}$ & $8.52 \pm 1.16^{\mathrm{a}}$ \\
\hline
\end{tabular}

Data are shown as mean \pm SEM; mean followed by the same letters are not significantly different at the 0.05 level (Duncan's multiple range test). Mean of three different rates of humic addition: control HA0 $\left(0 \mathrm{mg} \mathrm{L}^{-1}\right), \mathrm{HA} 0.2$ (2000 mg L $\left.{ }^{-1}\right)$, HA10 $\left(10,000 \mathrm{mg} \mathrm{L}^{-1}\right)$, and HA20 $\left(20,000 \mathrm{mg} \mathrm{L}^{-1}\right)$ of oxidized brown coal humic fertilizers $\mathrm{m}^{2} \mathrm{yr}^{-1}$, respectively.

The RHGR of $P$. sibirica increased significantly with $\mathrm{HA}_{0.2}$ treatment compared to $\mathrm{H}_{0}$ treatment during the years studied. With $\mathrm{HA}_{10}$ treatment (2011-2012) the RHGR of P. sibirica increased significantly compared to the $\mathrm{H}_{0}$ treatments. For 2013-2014, the RHGR of $P$. sibirica showed no sigificant differences with the $\mathrm{HA}_{10}$ and $\mathrm{H}_{0}$ treatments. The RHGR level of P. sibirica was not significantly different for all treatments within the study period, with the addition of the $\mathrm{H}_{20}$ treatment being comparative to the $\mathrm{HA}_{0}$ treatment. In the course of the survey, the P. sibirica RHGR range was $5.32 \pm 9.25 \mathrm{~cm} \mathrm{month}^{-1}$ or uneven growth.

The RHGR level was significantly larger for the treatments with increased exposure to brown coal humic fertilizer as compared to the control treatments (Table 1). The RHGR of A. tataricum significantly decreased over the years $\left(6.74,5.12,3.54\right.$, and $2.45 \mathrm{~cm} \mathrm{month}^{-1}$, respectively). However, in 2011 the RHGR was not significantlyaffected, and in 2012, 2013, and 2014, there was a rapid increase in RHGR for $\mathrm{HA}_{10}$ and $\mathrm{HA}_{20}$ treatments. In the course of the survey, the A. tataricum RHGR range was $2.45 \pm 7.80 \mathrm{~cm} \mathrm{month}^{-1}$, or uneven growth.

The RHGR of Salix ledebouriana was significantly moderate for the treatments with increased exposure to brown coal humic fertilizer compared to control treatments (Table 1). The highest RHGR increase was observed in $\mathrm{HA}_{20}$ in brown coal humic acid fertilizer treatments between 2011 and 2013. However, the $\mathrm{HA}_{10}, \mathrm{HA}_{0.2}$ and $\mathrm{HA}_{0}$ treatments had less effect on RHGR over the years. There were no significant differences in the treatments within 2014 and, in comparison with other years all treatments had significantly increased RHGR. In the course of the survey, the $S$. ledebouriana RHGR range was $2.45 \pm 7.80 \mathrm{~cm} \mathrm{month}^{-1}$ or uneven growth.

\subsection{The Comparative Analysis of RHGR during Monitoring Period}

The response of humic acid application and different treatments on plant growth characteristics is presented in Figure 1. 


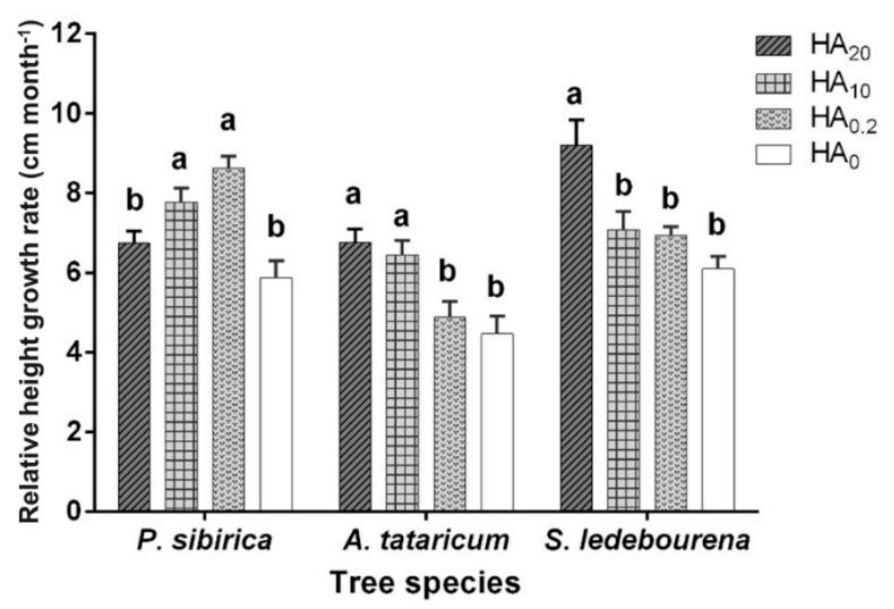

Figure 1. The comparative analysis of different treatment and years with RHGR. Humic acid was applied at $\mathrm{HA}_{20}\left(20,000 \mathrm{mg} \mathrm{L}^{-1}\right), \mathrm{HA}_{10}\left(10,000 \mathrm{mg} \mathrm{L}^{-1}\right), \mathrm{HA}_{0.2}\left(2000 \mathrm{mg} \mathrm{L}^{-1}\right)$, and $\mathrm{HA}_{0}\left(0 \mathrm{mg} \mathrm{L}^{-1}\right)$ oxidized brown coal humic fertilizers $\mathrm{m}^{2} \mathrm{yr}^{-1}$, respectively. Mean followed by the same letters are not significantly different at the 0.05 level (Duncan's multiple range test).

Results indicate that humic acid treatments significantly increased the relative height growth rate of trees during the four-year period. Based on the increment observed, the RHGR mean ratios obtained for P. sibirica, A. tataricum, and S. ledebouriana were $7.25,5.63$, and $7.32 \mathrm{~cm} \mathrm{month}^{-1}$, respectively. The interaction effect between oxidized brown coal humic fertilizers with trees RHGR from the HA $\mathrm{H}_{20}$, $\mathrm{HA}_{10}, \mathrm{HA}_{0.2}$ and $\mathrm{HA}_{0}$ treatments for each area was evaluated by comparing the highest between $S$. ledebouriana and the A. tataricum alternative; humic acid is shown to lower the intensity of the norm, with the $P$. sibirica $\mathrm{HA}_{0.2}$ and $\mathrm{HA}_{10}$ scenario showing the highest intensity value (Figure 1 ). In the comparative analysis of $A$. tataricum, when treated with $\mathrm{HA}_{10}$ and $\mathrm{HA}_{20}$ treatments, had shown significant RHGR. The different $S$. ledebouriana RHGR traits ranged from 6.09 to $9.19 \mathrm{~cm} \mathrm{month}^{-1}$, with the values of $\mathrm{HA}_{0}, \mathrm{HA}_{0.2}$ and $\mathrm{HA}_{10}$ treatments being the lowest and those of the $\mathrm{HA}_{20}$ treatments being the highest.

\subsection{Effect of Soil Chemical Properties on Fertilization}

The effect of oxidized brown coal humic acid fertilization treatments on soil chemical properties was significantly affected $(p<0.05)$ compared to control treatment (Table 3$)$.

Table 3. Soil chemical property of soil following brown coal humic acid fertilizer application.

\begin{tabular}{|c|c|c|c|c|c|c|c|c|c|}
\hline \multirow{2}{*}{ Treat } & \multirow{2}{*}{$\mathrm{pH}$} & \multirow{2}{*}{ EC } & \multirow{2}{*}{$\mathrm{CO}_{2}$} & \multirow{2}{*}{ OM } & \multirow{2}{*}{$\mathrm{NO}_{3}$} & \multicolumn{2}{|c|}{ Assimilable } & \multicolumn{2}{|c|}{ Exchangeable } \\
\hline & & & & & & $\mathrm{P}_{2} \mathrm{O}_{5}$ & $\mathrm{~K}_{2} \mathrm{O}$ & $\mathrm{Ca}$ & $\mathrm{Mg}$ \\
\hline $\mathrm{HA}_{0}$ & $8.32 \pm 0.04^{a}$ & $7.58 \pm 0.54^{c}$ & $0.75 \pm 0.48^{\mathrm{a}}$ & $0.39 \pm 0.01^{b}$ & $0.96 \pm 0.02^{a}$ & $0.86 \pm 0.04^{\mathrm{d}}$ & $10.22 \pm 0.70^{b}$ & $8.60 \pm 0.17^{a}$ & $3.20 \pm 0.14^{a}$ \\
\hline $\mathrm{HA}_{0.2}$ & $8.25 \pm 0.08^{a}$ & $9.92 \pm 0.23^{b}$ & $0.45 \pm 0.01^{b}$ & $0.41 \pm 0.01^{b}$ & $0.70 \pm 0.06^{\mathrm{b}}$ & $1.66 \pm 0.10^{\mathrm{c}}$ & $17.22 \pm 0.43^{a}$ & $7.00 \pm 0.40^{b}$ & $4.20 \pm 0.15^{\mathrm{a}}$ \\
\hline $\mathrm{HA}_{20}$ & $8.23 \pm 0.11^{\mathrm{a}}$ & $9.92 \pm 0.32^{b}$ & $0.40 \pm 0.01^{b c}$ & $0.42 \pm 0.02^{b}$ & $0.69 \pm 0.02^{b}$ & $2.88 \pm 0.14^{\mathrm{a}}$ & $16.25 \pm 0.61^{a}$ & $6.74 \pm 0.43^{b}$ & $4.24 \pm 0.28^{a}$ \\
\hline
\end{tabular}

According to the analysis results, the treatments of $\mathrm{HA}_{0.2}, \mathrm{HA}_{10}, \mathrm{HA}_{20}$ significantly increased the $\mathrm{EC}$, and $\mathrm{K}_{2} \mathrm{O}$, but significantly reduced $\mathrm{CO}_{2}$ and $\mathrm{NO}_{3}$ contents compared to the control treatments. $\mathrm{P}_{2} \mathrm{O}_{5}$ was statistically significant and increased among all the treatments. $\mathrm{pH}$ and $\mathrm{Mg}$ were not significantly affected much by all the treatments. In the $\mathrm{HA}_{10}$ treatment, $\mathrm{OM}$ significantly increased compared to the control treatment, but there was no significant increase in the $\mathrm{HA}_{0.2}$ and $\mathrm{HA}_{20}$ relatively. In the $\mathrm{HA}_{0.2}$ and $\mathrm{HA}_{20}$ treatments, Ca significantly decreased as compared to the $\mathrm{HA}_{0}$ treatment. 


\section{Discussion}

The findings from this study suggest that humic acid fertilizer concentrations had a significant effect on all growth traits with the treatments of $\mathrm{HA}_{20}, \mathrm{HA}_{10}, \mathrm{HA}_{0.2}$, and $\mathrm{HA}_{0}$. Monthly RHGR during the study years showed that trees treated with humic fertilizer treatments grew significantly more. The study showed increased HS concentration with significant monthly increase in RHGR of P. sibirica and S. ledebouriana species. In other related experimental studies, HA application increased the cumulative effect was the enhanced growth of plants and an increased yield of dry matter [47-52]. The increase of root growth in most cases is more visible than the stimulation of shoot growth $[50,53]$. Studies on the effects of HS on plant growth, under conditions of adequate mineral nutrition, consistently show positive effects on plant biomass [13,51]. Overall, random effects meta-analysis estimated a shoot dry weight increase of $22 \%$ and a root dry weight increase of $21 \%$ in response to HS application [3]. This study showed that, RHGR of $A$. tataricum significantly decreased over the years with $\mathrm{HA}_{0}$ treatments. A. tataricum decreased over the years to an extent that significantly influenced HA fertilizer on the height growth rates. HS affected most plant metabolic processes, regardless of their source, by controlling enzymatic systems related to primary, secondary, and defense metabolisms as a reaction to environmental stress [53,54]. The results of this study are consistent with whatever metabolic pathways for humic matter affected plant growth and development, hormonal, carbon, and nitrogen metabolisms and stress response $[29,50,55]$. These results are quite useful, especially in the field of agronomic HS use, because soil weathering, climate change, and limited water and nutrient resources are becoming increasingly important challenges in agricultural production, and guidance for using HS is often directed at alleviating these stresses $[19,53,56]$. In a related study, the typical response curve showed increased HS concentration with increased plant growth solutions, followed by decrease in growth at very high concentrations $[57,58]$.

In the present study, the treatments of $\mathrm{HA}_{0.2}, \mathrm{HA}_{10}$, and $\mathrm{HA}_{20}$ significantly increased the soil's $\mathrm{EC}$, and $\mathrm{K}_{2} \mathrm{O}$, whereas the content of $\mathrm{CO}_{2}$ and $\mathrm{NO}_{3}$ was significantly reduced as compared to control. These results are consistent with previous studies on soil physicochemical properties; in particular, soil organic matter content and nutrient concentrations increased [32,50,53,59]. $\mathrm{P}_{2} \mathrm{O}_{5}$ was statistically different and increased among all the treatments. In another related study, phosphorus concentrations increased with increasing levels of humic acid regardless of the yield response [32,49,60]. The effect of phosphorus absorption was the opposite of that relating to nitrogen-absorption increasing with higher doses [61]. HA and phosphorus applications increased the growth parameter of the plants [58]. Technically, HA is not a fertilizer, even though in some studies it is described as such [7]. In some instances, the use of fertilizers could be stopped at once if there is enough organic material allowing the soil to be fully dependent on microbial processes and humus production to sustain itself $[9,53,62]$.

\section{Conclusions}

Our study revealed a positive effect of oxidized brown coal humic fertilizers on tree growth even though the humic fertilizer concentrations may differ depending on the species. Planted tree growth treated with HS was compared with RHGR tests. Specifically, A. tataricum decreased over the years to an extent that was statistically significant for high growth rates. However, there was a variety of impacts on growth due to the adaptability of the tree species and the ecological environment. The experimental site soil, with a very high sodium content ( $\mathrm{pH}$ of 8.23 to 8.32) and $\mathrm{Mg}$, was significantly unchanged during HA fertilization treatments. Nonetheless, the increase in the assimilable $\mathrm{K}_{2} \mathrm{O}, \mathrm{P}_{2} \mathrm{O}_{5}$, and $\mathrm{OM}$ may have positively affected tree growth. Findings from this experiment show that the application of oxidized brown coal humic fertilizer can positively affect the RHGR of planted trees and certain adaptability traits related to it. Therefore, further studies will be needed for long-term monitoring, including those in which species of trees and soil types necessary for specific objectives in different ecological conditions. 
Author Contributions: K.A. and G.T. designed and sampled; W.C., S.L., C.E.J., R.C., and R.W.C. contributed to data analysis and interpretation; K.A. and K.H.D. provided technical advice and support for this study; G.T. wrote the paper.

Acknowledgments: This study was supported by the Division for Desertification Study at Institute of Geography and Geoecology, Mongolian Academy of Sciences, Dongguk University Research Program of 2017 and, the "Forest Science and Technology Development" project (Project No. S211215L030110) funded by the Korea Forest Service. In addition, we appreciate the soil research support provided by Delgertsetseg R. (Soil laboratory, Division of Soil Science at the Institute of Geography and Geoecology, Mongolian Academy of Science) and Dugarjav J. (Institute of Chemistry and Chemical Technology, Mongolian Academy of Sciences).

Conflicts of Interest: The authors declare no conflict of interest.

\section{References}

1. Lehmann, J.; Kleber, M. The contentious nature of soil organic matter. Nature 2015, 528, 60. [CrossRef] [PubMed]

2. Parolo, M.E.; Savini, M.C.; Loewy, R.M. Characterization of soil organic matter by FT-IR spectroscopy and its relationship with chlorpyrifos sorption. J. Environ. Manag. 2017, 196, 316-322. [CrossRef] [PubMed]

3. Rose, M.T.; Patti, A.F.; Little, K.R.; Brown, A.L.; Jackson, W.R.; Cavagnaro, T.R. A meta-analysis and review of plant-growth response to humic substances: Practical implications for agriculture. In Advances in Agronomy; Elsevier: Victoria, VIC, Australia, 2014; Volume 124, pp. 37-89.

4. Tahiri, A.; Delporte, F.; Muhovski, Y.; Ongena, M.; Thonart, P.; Druart, P. Change in ATP-binding cassette $\mathrm{B} 1 / 19$, glutamine synthetase and alcohol dehydrogenase gene expression during root elongation in Betula pendula Roth and Alnus glutinosa L. Gaertn in response to leachate and leonardite humic substances. Plant Physiol. Biochem. 2016, 98, 25-38. [CrossRef] [PubMed]

5. Wershaw, R. Model for humus in soils and sediments. Environ. Sci. Technol. 1993, 27, 814-816. [CrossRef]

6. Canieren, O.; Karaguzel, C.; Aydin, A. Effect of physical pre-enrichment on humic substance recovery from leonardite. Physicochem. Probl. Miner. Process. 2017, 53, 502-514.

7. Hayashi, J.-I.; Li, C.-Z. Structure and properties of Victorian brown coal. In Advances in the Science of Victorian Brown Coal; Elsevier: Victoria, VIC, Australia, 2004; pp. 11-84.

8. Karaman, M.; Turan, M.; Tutar, A.; Dizman, M.; Şahin, S. Possible Use of Leonardite-Based Humate Sources as a Potential Organic Fertilizer. In Functions of Natural Organic Matter in Changing Environment; Springer: Berlin, Germany, 2013; pp. 1061-1065.

9. Tan, K.H. Humic Matter in Soil and the Environment: Principles and Controversies; CRC Press: Boca Raton, FL, USA, 2014.

10. Antosovd, B.; Novak, J.; Kozler, J.; Kubicek, J.; Kimmerovd, I. Methodic for testing biological activities of humic substances in higher plants. In Reactive and Functional Polymers Research Advances; Nova Publishers: Ústí nad Labem, US, Chech Republic, 2008; p. 191.

11. Nardi, S.; Pizzeghello, D.; Schiavon, M.; Ertani, A. Plant biostimulants: Physiological responses induced by protein hydrolyzed-based products and humic substances in plant metabolism. Sci. Agric. 2016, 73, 18-23. [CrossRef]

12. Orsi, M. Molecular dynamics simulation of humic substances. Chem. Biol. Technol. Agric. 2014, 1, 10. [CrossRef]

13. Yang, C.-M.; Wang, M.-C.; Lu, Y.-F.; Chang, F.; Chou, C.-H. Humic substances affect the activity of chlorophyllase. J. Chem. Ecol. 2004, 30, 1057-1065. [CrossRef] [PubMed]

14. Arbuzov, S.I.; Volostnov, A.; Mezhibor, A.M.; Rybalko, V.; Ilenok, S.S. Scandium (Sc) geochemistry in coals (Siberia, Russian Far East, Mongolia, Kazakhstan, and Iran). Int. J. Coal Geol. 2014, 125, 22-35. [CrossRef]

15. O'donnell, R. The auxin-like effects of humic preparations from leonardite. Soil Sci. 1973, 116, $106-112$. [CrossRef]

16. Petrov, D.; Tunega, D.; Gerzabek, M.H.; Oostenbrink, C. Molecular dynamics simulations of the standard leonardite humic acid: Microscopic analysis of the structure and dynamics. Environ. Sci. Technol. 2017, 51, 5414-5424. [CrossRef] [PubMed]

17. Adani, F.; Tambone, F.; Davoli, E.; Scaglia, B. Surfactant properties and tetrachloroethene (PCE) solubilisation ability of humic acid-like substances extracted from maize plant and from organic wastes: A comparative study. Chemosphere 2010, 78, 1017-1022. [CrossRef] [PubMed]

18. Arancon, N.Q.; Edwards, C.A.; Lee, S.; Byrne, R. Effects of humic acids from vermicomposts on plant growth. Eur. J. Soil Biol. 2006, 42, S65-S69. [CrossRef] 
19. Kulikova, N.; Stepanova, E.; Koroleva, O. Mitigating activity of humic substances: Direct influence on biota. In Use of Humic Substances to Remediate Polluted Environments: From Theory to Practice; Springer: Dordrecht, The Netherlands, 2005; pp. 285-309.

20. Turan, M.A.; Baris, B.A.; Katkat, A.V.; Celik, H. The effects of soil-applied humic substances to the dry weight and mineral nutrient uptake of maize plants under soil-salinity conditions. Not. Bot. Hort. Agrobot. Cluj-Napoca 2011, 39, 171. [CrossRef]

21. Mohammadpourkhaneghah, A.; Shahryari, R.; Alaei, Y.; Shahmoradmoghanlou, B. Comparison of the effect of liquid humic fertilizers on yield of maize genotypes in Ardabil region. Afr. J. Biotechnol. 2012, 11, 4810-4814. [CrossRef]

22. Huang, P.-M.; Wang, M.-K.; Chiu, C.-Y. Soil mineral-organic matter-microbe interactions: Impacts on biogeochemical processes and biodiversity in soils. Pedobiologia 2005, 49, 609-635. [CrossRef]

23. Kline, S.W.; Wilson, C.E., Jr. Proposal for Experimentation with Arkansas Lignite to Identify Organic Soil Supplements Suitable to Regional Agricultural Needs; Preliminary Draft; Arkansas Tech University: Russellville, AR, USA, 1994.

24. Schulten, H.-R.; Plage, B.; Schnitzer, M. A chemical structure for humic substances. Naturwissenschaften 1991, 78, 311-312. [CrossRef] [PubMed]

25. Stott, D.; Martin, J. Synthesis and degradation of natural and synthetic humic material in soils. Hum. Subst. Soil Crop Sci. Sel. Read. 1990, 37-63. [CrossRef]

26. Kumar, D.; Singh, A.; Raha, P.; Rakshit, A.; Singh, C.; Kishor, P. Potassium humate: A potential soil conditioner and plant growth promoter. Int. J. Agric. Environ. Biotechnol. 2013, 6, 441-446. [CrossRef]

27. Little, K.R.; Rose, M.T.; Jackson, W.R.; Cavagnaro, T.R.; Patti, A.F. Do lignite-derived organic amendments improve early-stage pasture growth and key soil biological and physicochemical properties? Crop Pasture Sci. 2014, 65, 899-910. [CrossRef]

28. Richter, M.K.; Sander, M.; Krauss, M.; Christl, I.; Dahinden, M.G.; Schneider, M.K.; Schwarzenbach, R.P. Cation binding of antimicrobial sulfathiazole to leonardite humic acid. Environ. Sci. Technol. 2009, 43, 6632-6638. [CrossRef] [PubMed]

29. Trevisan, S.; Francioso, O.; Quaggiotti, S.; Nardi, S. Humic substances biological activity at the plant-soil interface: From environmental aspects to molecular factors. Plant Signal. Behav. 2010, 5, 635-643. [CrossRef] [PubMed]

30. Meshram, P.; Purohit, B.K.; Sinha, M.K.; Sahu, S.; Pandey, B. Demineralization of low grade coal-A review. Renew. Sustain. Energy Rev. 2015, 41, 745-761. [CrossRef]

31. Purevsuren, B. Coal Is the Main Source of Energy in Mongolia. In Proceedings of the Second Korean and Mongolian Energy Conference, Yonsei University, Seoul, Korea, 26 June 2007; p. 13.

32. Ece, A.; Saltali, K.; Eryigit, N.; Uysal, F. The effects of leonardite applications on climbing bean (Phaseolus vulgaris L.) yield and the some soil properties. J. Agron. 2007, 6, 480.

33. Khaulenbek, A.M.N.; Munkhnasan, L.; Ganchudur, Ts.; Bataa, D.; Itgelt, N.; Gurragchaa, T.; Nyamdash, S. Baseline Study Report of Situation and Assessment of Desertification in Central Mongolian Steppe Region; Institute of Geography\&Geoecology: Ulaanbaatar, Mongolia, 2004; pp. 22-45.

34. Maki, A.; Kenji, T.; Kiyokazu, K.; Teruo, H. Morphological and physico-chemical characteristics of soils in a steppe region of the Kherlen River basin, Mongolia. J. Hydrol. 2007, 333, 100-108. [CrossRef]

35. Yamamura, N.; Fujita, N.; Maekawa, A. The Mongolian Ecosystem Network: Environmental Issues under Climate and Social Changes; Springer: Tokyo, Japan, 2012.

36. Gunin, P.D.; Vostokova, E.A.; Dorofeyuk, N.I.; Tarasov, P.E.; Black, C.C. Vegetation Dynamics of Mongolia; Springer Nature: Berlin/Heidelberg, Germany, 2013; Volume 26.

37. Lomovsky, O.I.D.J.; Tsogtbaatar, J. Use of Non-Energy Coal to Combat Desertification; Short Reports of Joint Projects Completed in 2011-2012 with the Participation of the Ministry of Education and Science of Mongolia; The Siberian Branch of the Russian Academy of Sciences and Academy of Sciences of Mongolia: Bulgaria, Mongolia, 2013; pp. 14-22.

38. Tsogtbaatar, J. Deforestation and reforestation needs in Mongolia. For. Ecol. Manag. 2004, 201, 57-63. [CrossRef]

39. Meusel, H.; Jager, E. Ecogeographical differentiation of the Submediterranean. In Woody Plants-Evolution and Distribution Since the Tertiary Proceedings of the Symposium Organized by Deutsche Akademie der Naturforscher LEOPOLDINA, Halle/Saale, German, 9-11 October 1986; Springer: Berlin, Germany, 1986. 
40. Schollenberger, C.J.; Simon, R.H. Determination of exchange capacity and exchangeable bases in soil-ammonium acetate method. Soil Sci. 1945, 59, 13-24. [CrossRef]

41. Sherrod, L.; Dunn, G.; Peterson, G.; Kolberg, R. Inorganic carbon analysis by modified pressure-calcimeter method. Soil Sci. Soc. Am. J. 2002, 66, 299-305. [CrossRef]

42. Walkley, A.; Black, I.A. An examination of the Degtjareff method for determining soil organic matter, and a proposed modification of the chromic acid titration method. Soil Sci. 1934, 37, 29-38. [CrossRef]

43. Okalebo, J.R.; Gathua, K.W.; Woomer, P.L. Laboratory Methods of Soil and Plant Analysis: A Working Manual, 2nd ed.; Sacred Africa Publishers: Nairobi, Kenya, 2002.

44. Hunt, R. Plant Growth Curves. The Functional Approach to Plant Growth Analysis; Edward Arnold Ltd.: London, UK, 1982.

45. Pommerening, A.; Muszta, A. Methods of modelling relative growth rate. For. Ecosyst. 2015, 2, 5. [CrossRef]

46. Van den Driessche, R. Absolute and relative growth of Douglas-fir seedlings of different sizes. Tree Physiol. 1992, 10, 141-152. [CrossRef] [PubMed]

47. Nardi, S.; Pizzeghello, D.; Muscolo, A.; Vianello, A. Physiological effects of humic substances on higher plants. Soil Biol. Biochem. 2002, 34, 1527-1536. [CrossRef]

48. Salati, S.; Papa, G.; Adani, F. Perspective on the use of humic acids from biomass as natural surfactants for industrial applications. Biotechnol. Adv. 2011, 29, 913-922. [CrossRef] [PubMed]

49. Sugier, D.; Kołodziej, B.; Bielińska, E. The effect of leonardite application on Arnica montana L. yielding and chosen chemical properties and enzymatic activity of the soil. J. Geochem. Explor. 2013, 129, 76-81. [CrossRef]

50. Tahiri, A.; Destain, J.; Thonart, P.; Druart, P. In vitro model to study the biological properties of humic fractions from landfill leachate and leonardite during root elongation of Alnus glutinosa L. Gaertn and Betula pendula Roth. Plant Cell Tissue Organ Cult. (PCTOC) 2015, 122, 739-749. [CrossRef]

51. Ertani, A.; Francioso, O.; Tugnoli, V.; Righi, V.; Nardi, S. Effect of commercial lignosulfonate-humate on Zea mays L. metabolism. J. Agric. Food Chem. 2011, 59, 11940-11948. [CrossRef] [PubMed]

52. Kononova, M. Soil organic matter. Soil Sci. 1963, 95, 90. [CrossRef]

53. Berbara, R.L.; García, A.C. Humic substances and plant defense metabolism. In Physiological Mechanisms and Adaptation Strategies in Plants under Changing Environment; Springer: New York, NY, USA, 2014; pp. 297-319.

54. Nosir, W.; Abdelkader, M.A. Effect of natural Additives on Nigella sativa Growth in Hydroponic System. Future 2017, 2, 11-30.

55. Pizzeghello, D.; Nicolini, G.; Nardi, S. Hormone-like activity of humic substances in Fagus sylvaticae forests. New Phytol. 2001, 151, 647-657. [CrossRef]

56. Billingham, K. Humic products-Potential or Presumption for Agriculture? Can Humic Products Improve My Soil. In Proceedings of the 27th Annual Conference of the Grassland Society of NSW Inc., Orange, NSW, Australia, 24-26 July 2012; pp. 24-26.

57. Çimrin, K.M.; Türkmen, Ö.; Turan, M.; Tuncer, B. Phosphorus and humic acid application alleviate salinity stress of pepper seedling. Afr. J. Biotechnol. 2010, 9, 5845-5851.

58. Chen, Y.; Aviad, T. Effects of humic substances on plant growth 1. Hum. Subst. Soil Crop Sci. Sel. Read. 1990, 161-186. [CrossRef]

59. Saengwilai, P.; Meeinkuirt, W.; Pichtel, J.; Koedrith, P. Influence of amendments on Cd and Zn uptake and accumulation in rice (Oryza sativa L.) in contaminated soil. Environ. Sci. Pollut. Res. 2017, 24, 15756-15767. [CrossRef] [PubMed]

60. Sarir, M.; Sharif, M.; Zeb, A.; Akhlaq, M. Influence of different levels of humic acid application by variousmethods on the yield and yield components of maize. Sarhad J. Agric. 2005, 21, 75-81.

61. Ayuso, M.; Hernandez, T.; Garcia, C.; Pascual, J. Stimulation of barley growth and nutrient absorption by humic substances originating from various organic materials. Bioresour. Technol. 1996, 57, 251-257. [CrossRef]

62. Jafari, M.; Khanghah, A.M.; Alaei, Y.; Moosavi, S.S.; Khabiri, E. Comparison effect organic humic fertilizers the dry matter maize genotypes in Ardabil region. Life Sci. J. 2012, 9, 2746-2749.

(C) 2018 by the authors. Licensee MDPI, Basel, Switzerland. This article is an open access article distributed under the terms and conditions of the Creative Commons Attribution (CC BY) license (http://creativecommons.org/licenses/by/4.0/). 